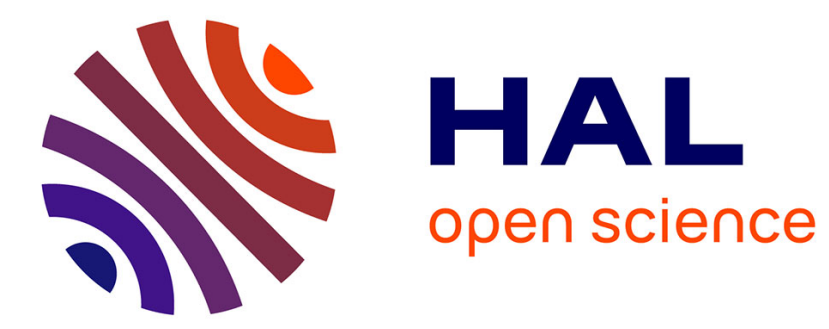

\title{
Optical Properties of Mixed Cobalt Ferrites
}

\author{
M. Lenglet, F. Hochu, J. Dürr
}

\section{To cite this version:}

M. Lenglet, F. Hochu, J. Dürr. Optical Properties of Mixed Cobalt Ferrites. Journal de Physique IV Proceedings, 1997, 07 (C1), pp.C1-259-C1-260. 10.1051/jp4:19971100 . jpa-00254721

\section{HAL Id: jpa-00254721 https://hal.science/jpa-00254721}

Submitted on 1 Jan 1997

HAL is a multi-disciplinary open access archive for the deposit and dissemination of scientific research documents, whether they are published or not. The documents may come from teaching and research institutions in France or abroad, or from public or private research centers.
L'archive ouverte pluridisciplinaire HAL, est destinée au dépôt et à la diffusion de documents scientifiques de niveau recherche, publiés ou non, émanant des établissements d'enseignement et de recherche français ou étrangers, des laboratoires publics ou privés. 


\title{
Optical Properties of Mixed Cobalt Ferrites
}

\author{
M. Lenglet, F. Hochu* and J. Dür** \\ L.A.S.T.S.M., Université de Rouen, 76821 Mont-Saint-Aignan, France \\ * École des Mines de Douai, 59508 Douai, France
}

\begin{abstract}
The optical properties of $\mathrm{Co}$ and $\mathrm{Mg}$ ferrigallate spinels have been studied near the magnetic transition. The cluster $\left(\mathrm{CoFeO}_{10}\right)^{15-}$ is characterized by a strong intensification of iron pair excitations and by the existence in ferrimagnetic compounds of a large electronic transition assigned to $\mathrm{Co}^{2+} \rightarrow \mathrm{Fe}^{3+}$ metal-metal charge transfer at $1.70-1.75 \mathrm{eV}$.
\end{abstract}

The optical spectra of transition-group metal ions have been the subject of intense investigations attempted in order to obtain a fundamental understanding of the varied colors and luminescent properties exhibited by the internal transitions in different crystalline enviromments. Some much more intense absorptions are due to electron transfer : LMCT (ligand-metal charge transfer), IVCT (intervalence charge transfer) and MMCT (metal-metal charge transfer). The purpose of this paper is to present the influence of superexchange interactions on the optical spectrum of the cluster $\left(\mathrm{CoFeO}_{10}\right)^{15-}$ in the spinel structure. The compounds chosen to illustrate the influence of superexchange interactions on the $\mathrm{Co}^{2+} \rightarrow \mathrm{Fe}^{3+}$ metal-metal charge transfer belong to the $\mathrm{CoFe}_{2-x} \mathrm{Ga}_{x} \mathrm{O}_{4}$ system. In order to get a better insight of the local environment of cobalt and iron in these spinels, the EXAFS spectra were recorded at the Fe and Co K-edge and analyzed. the structural parameters do not reveal important fluctuations of $M-O$ distances in the analyzed compounds $(x=0,0.5,1,1.4,2)$.

$\begin{array}{lll} & \text { 4-fold coordination } & \text { 6-fold coordinati }(\mathrm{mm}) \\ \mathrm{Co}-\mathrm{O}(\mathrm{nm}) & 0.204 \pm 0.002 & 0.199 \pm 0.002 \\ & 0.192 \pm 0.002 & 0.191 \pm 0.002\end{array}$

\section{$\mathrm{Co}^{2+} \rightarrow \mathrm{Fe}^{3+}$ transfer and superexchange interactions in mixed cobalt ferrites.}

The substitution of the tetrahedral and octahedral $\mathrm{Fe}^{3+}$ ions by non-magnetic $\mathrm{Ga}^{3+}$ ions in $\mathrm{Li}_{0.5} \mathrm{Fe}_{2.5} \mathrm{O}_{4}[1]$ and $\mathrm{MgFe}_{2} \mathrm{O}_{4}$ (Fig. 1) provides a possibility for experimentally distinguishing transitions from various sites. From these studies the following conclusions may be drawn :

- in $\mathrm{Li}_{0.5} \mathrm{Fe}_{2.5} \mathrm{O}_{4}$ and $\mathrm{MgFe}_{2} \mathrm{O}_{4}$ ferrites the ligand field transitions unaffected by a double exciton process are strongly enhanced by the A-B interactions. The band at $19000 \mathrm{~cm}^{-1}(2.35 \mathrm{eV})$ is a composite of the ${ }^{6} \mathrm{~A}_{1} \rightarrow{ }^{4} \mathrm{~T}_{2}\left({ }^{4} \mathrm{G}\right)$ ligand field transition of tetrahedral $\mathrm{Fe}^{3+}$ and ${ }^{6} \mathrm{~A}_{1}+{ }^{6} \mathrm{~A}_{1} \rightarrow{ }^{4} \mathrm{~T}_{1}+{ }^{4} \mathrm{~T}_{1}\left({ }^{4} \mathrm{G}\right)$ pair transition.

- the gallium substitution influences the nature of interactions : as the gallium content is increased, the intersublattice interaction weaken and the intrasublattice become stronger facilitating a canted spin alignment on the octahedral sites. This phenomenon induces a strong intensification of pair transitions : ${ }^{6} \mathrm{~A}_{1} \rightarrow{ }^{4} \mathrm{E}_{1}{ }^{4} \mathrm{~A}_{1}, 2{ }^{6} \mathrm{~A}_{1} \rightarrow{ }^{4} \mathrm{~T}_{1}+{ }^{4} \mathrm{~T}_{2}$ near $21500 \mathrm{~cm}^{-1}$ (2.66 $\mathrm{eV})$ and $2{ }^{6} \mathrm{~A}_{1} \rightarrow\left(\mathrm{E}_{1},{ }^{4} \mathrm{~A}_{1}\right)+{ }^{4} \mathrm{~T}_{1}$ near $28500 \mathrm{~cm}^{-1}(3.53 \mathrm{eV})$

- in paramagnetic compounds, the absorption coefficient $\mathbf{k}$ for the $\mathrm{Fe}^{3+}$ ion in tetrahedral coordination is ten times higher than that of octahedral $\mathrm{Fe}^{3+}$.

The influence of a strong antiferromagnetic coupling on the electronic spectrum $(0.5-4 \mathrm{eV})$ of gallium-substituted cobalt ferrites containing $\mathrm{Fe}^{3+}$ and $\mathrm{Co}^{2+}$ cations octahedral coordinated has been studied. The analysis of the difference spectra $\mathrm{CoFe}_{2-\mathrm{x}} \mathrm{Ga}_{\mathrm{x}} \mathrm{O}_{4}-\mathrm{CoGa}_{2} \mathrm{O}_{4}$ and $\mathrm{CoFe}_{2-\mathrm{x}} \mathrm{Ga}_{\mathrm{x}} \mathrm{O}_{4}-\mathrm{MgFe}_{2-\mathrm{x}} \mathrm{Ga}_{\mathrm{x}} \mathrm{O}_{4}$ (fig. 2, $\mathrm{x}=0$ ) reveals for ferrimagnetic compounds (0 $\leq \mathrm{x} \leq 1$ ) in the range $1.5-3 \mathrm{eV}$ a strong enhancement of iron (III) pair transition and the existence of an intense electronic transition assigned to the $\mathrm{Co}^{2+}+\mathrm{Fe}^{3+} \rightarrow \mathrm{Co}^{3+}+\mathrm{Fe}^{2+}$ intervalence charge transfer at $1.70-1.75 \mathrm{eV}$ (Table1). 


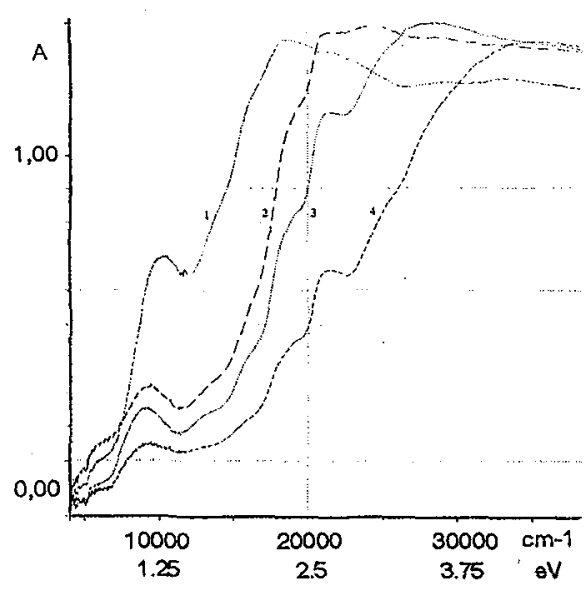

Fig. 1. UV-Vis-NIR spectra of iron (III) in the $\mathrm{MgFe}_{2-x} \mathrm{Ga}_{x} \mathrm{O}_{4}$ system near the magnetic transition : (1) $\mathrm{x}=0$; (2) $\mathrm{x}=0.6$; (3) $\mathrm{x}=1$ and (4) $\mathrm{x}=1.5$

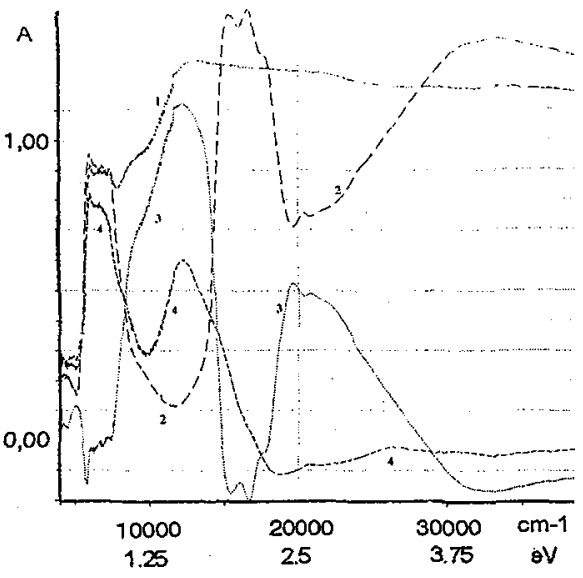

Fig. 2. Difference spectra (curve 3) between $\mathrm{CoFe}_{2} \mathrm{O}_{4}$ (1) and $\mathrm{CoGa}_{2} \mathrm{O}_{4}(2)$ and between $\mathrm{CoFe}_{2} \mathrm{O}_{4}$ and $\mathrm{MgFe}_{2} \mathrm{O}_{4}$ (curve 4)

Table 1. Analysis of the difference spectra. Energy in $\mathrm{eV}$ and assignment of the observed bands

\begin{tabular}{|c|c|c|c|c|c|}
\hline \multirow[b]{2}{*}{$\mathrm{x}$} & \multirow[b]{2}{*}{$\mathrm{Fe}^{3+}{ }^{6} \mathrm{~A}_{1} \rightarrow{ }^{4} \mathrm{~T}_{1}$} & \multicolumn{2}{|c|}{$\mathrm{CoFe}_{2-\mathrm{G}} \mathrm{Ga}_{\mathrm{x}} \mathrm{O}_{4}-\mathrm{CoGa}_{2} \mathrm{O}_{4}$} & \multirow[b]{2}{*}{$\begin{array}{l}\mathrm{Fe}^{3+} \text { pair } \\
\text { transition }\end{array}$} & \multirow[b]{2}{*}{$\begin{array}{c}\theta_{c}\left({ }^{\circ} \mathrm{C}\right) \text { of the } \\
\mathrm{CoFe}_{2-x} \mathrm{Ga}_{x} \mathrm{O}_{4} \text { spinels }\end{array}$} \\
\hline & & $\operatorname{MMCT}\left(\mathrm{Co}^{2+} \rightarrow \mathrm{Fe}^{3+}\right)$ & $\begin{array}{r}\mathrm{Fe}^{3+}{ }^{6} \mathrm{~A}_{1} \rightarrow{ }^{4} \mathrm{~T}_{2} \\
\text { and }{ }^{6} \mathrm{~A}_{1} \rightarrow{ }^{4} \mathrm{E}_{1},{ }^{4} \mathrm{~A}_{1}\end{array}$ & & \\
\hline 0 & 1.18 & $1.74(1)$ & $2.48(1)$ & & 520 \\
\hline 0.5 & $\sim 1.24$ & $1.74(0.98)$ & $2.45-2.60(0.94)$ & & 357 \\
\hline 1 & $\sim 1.24$ & $1.74(0.75)$ & $2.42-2.60(0.98)$ & & 194 \\
\hline 1.5 & 1.21 & $1.70(0.26)$ & $2.48(0.58)$ & 2.79 & 0 \\
\hline $\mathrm{x}$ & $\mathrm{Co}^{2+} \mathrm{d}-\mathrm{d}$ & MMCT $\mathrm{CoFe}_{2-x}$ & $\begin{array}{l}\mathrm{xO}_{4}-\mathrm{MgFe}_{2-\mathrm{x}} \mathrm{Ga}_{\mathrm{x}} \mathrm{O}_{4} \\
\mathrm{Co}^{2+} \mathrm{d}-\mathrm{d}\end{array}$ & $\mathrm{Fe}^{3+}{ }^{6} \mathrm{~A}_{1} \rightarrow{ }^{4} \mathrm{~T}_{2}$ & $\mathrm{Fe}^{3+}$ pair transition \\
\hline 0 & $0.74-0.91$ & 1.70 & $2.03(0.81)$ & & \\
\hline 0.5 & $0.74-0.91$ & $1.82(0.93)$ & $2.03(0.81)$ & & \\
\hline 1 & $0.74-0.91$ & $1.86(0.93)$ & $2.03(0.89)$ & 2.38 & 2.72 \\
\hline 1.5 & $0.74-0.91$ & $1.91(0.80)$ & $2.06(0.80)$ & 2.40 & 2.85 \\
\hline $\mathrm{Ga}_{2} \mathrm{O}$ & $0.74-0.91$ & $\begin{array}{c}\mathrm{Co}^{2+}{ }^{4} \mathrm{~A}_{2} \\
1.91(0.96)\end{array}$ & $\begin{array}{l}\left({ }^{4} \mathrm{P}\right) \text { main components } \\
2.07(0.98)\end{array}$ & & \\
\hline
\end{tabular}

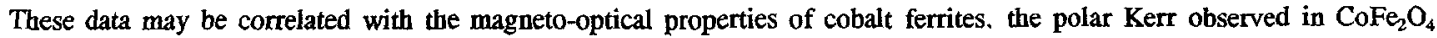
around $2 \mathrm{eV}$ is mainly due to the MMCT transition. in substituted $\mathrm{CoFe} 2 \mathrm{M}_{\mathrm{x}} \mathrm{O}_{4}$, the shift of the negative peak near $2 \mathrm{eV}$ on the polar Kerr rotation spectra to the high energies is assigned to a major contribution of the ${ }^{4} \mathrm{~A}_{2} \rightarrow{ }^{4} \mathrm{~T}_{1}\left({ }^{4} \mathrm{P}\right) \mathrm{Co}^{2+}$ tetrahedral transition $(\mathrm{M}=\mathrm{Al}, \mathrm{Cr})$ :

$$
\begin{array}{ccccccc} 
& \multicolumn{2}{c}{\mathrm{CoFe}_{2} \mathrm{O}_{4}} & \mathrm{CoFe}_{1.2} \mathrm{Al}_{0.8} \mathrm{O}_{4} & \mathrm{CoFeCrO}_{4} & \mathrm{CoFe}_{1.1} \mathrm{Mn}_{0.9} \mathrm{O}_{4} \\
\text { Energy (eV) } & 1.80[2] & 1.90-2.15[3] & 1.97[2] & 1.95-2.30[3] & 1.93[2] & 1.70[2]
\end{array}
$$

The reinvestigation of the optical properties of $\mathrm{MgFe}_{2} \mathrm{O}_{4}$ leads to the conclusion that the magneto-optical properties of this ferrite in the $2-5 \mathrm{eV}$ range may be correlated with $\mathrm{Fe}^{3+}$ tetrahedral and pair-transitions up to $4 \mathrm{eV}$ and LMCT transitions above $4 \mathrm{eV}$.

\section{References}

[1] Hochu F., Lenglet M., Jørgensen C.K., J. Solid State Chem. 120 (1995) 244-253.

[2] Abe M., Gomi M., J. Appl. Phys. 53 (1982) 8172-8174.

[3] Peters W.L., Martens J.W.D., J. Appl. Phys. 53 (1982) 8178-8180. 